\title{
In vitro anthelmintic efficacy of some indigenous medicinal plants against gastrointestinal nematodes of cattle
}

\author{
M. R. Amin, M. Mostofa, M. E. Hoque and M. A. Sayed \\ Department of Pharmacology, Bangladesh Agricultural University, Mymensingh-2202, Bangladesh
}

\begin{abstract}
The prevalence of natural gastrointestinal nematodes was observed in cattle during the period from June, 2004 to May, 2005 in Sadar upazila of Mymensingh district. The prevalence of gastrointestinal nematodes was $84.1 \%$ (rainy seasons-97\%, summer-85.5\% and winter seasons-69.8\%). The prevalence of strongyles (Haemonchus sp., Trichostrongylus sp., Oesophagostomum sp. and Mecistocirrus sp.), Bunostomum sp., Strongyloides sp., Trichuris sp. and Capillaria sp. were $63.9 \%, 26.3 \%, 21.5 \%, 17.3 \%$ and $24.5 \%$, respectively. Water extracts of 20 indigenous plants(neem, tobacco plant, barbados lilac, betel leaf, pineapple, jute, turmeric, garlic, devil's tree, papaya, lime tree, dodder, white teak, conessi tree, bitter gourd, sweet basil, white verticillia, pomegranate, sage, chaste tree) showed potential in vitro activities against adult parasites. Out of these, 20 plant extracts, 10 plants (neem, tobacco, barbados lilac, betel leaf, pineapple, jute, turmeric, garlic, dodder and bitter gourd) showed $100 \%$ efficacy against adult worms, 4 plants (devil's tree, papaya, white verticillia and chaste tree) showed $90-$ $98 \%$ and others (lime tree, white teak, conessi tree, sweet basil, pomegranate and sage) showed below $90 \%$.
\end{abstract}

Keywords: Anthelmintic, Gastrointestinal nematodes, In vitro, Prevalence, Medicinal plants

\section{Introduction}

Parasitism is an important limiting factor that responsible for deteriorating the health and productivity of livestock. The agro-ecological and geo-climatic conditions of Bangladesh are highly favorable for the growth and multiplication of parasites. As a result about 50\% apparently healthy cattle populations are affected with different species of parasites (Garrels, 1975). Infections by gastrointestinal helminth parasites of livestock are among the most common, which are considered as economically important diseases of grazing livestock (Perry et al., 2002). They are characterized by lower outputs of animal products (meat, milk, hides and skins), manure and traction, which all have impact of the livelihood of small holder farmers (Perry and Randolph, 1999). The production performances of these cattle are low, because of wide spread occurrence of pathogenic parasites. Parasitic diseases are considered important causing enormous economic losses through morbidity and mortality in livestock. Among the parasitic diseases, gastrointestinal nematodes such as Haemonchus spp., Trichostrongylus spp., Cooperia spp., Oesophagostomum spp., Trichuris spp. and Strongyloides spp. are most common (Qadir, 1981; Rahman and Mondal, 1983). Imported synthetic anthelmintics are considered the only effective way of controlling parasitic infection. However, as these are expensive and unavailable, livestock producers are not interested to use these anthelmintics. Furthermore, some serious disadvantages of using those anthelmintics, notably the development of resistance to helminth parasites (Waller and Prichard, 1985) against various anthelmintic compounds and classes, as well as their residues and toxicity problems (Kaemmerer and Butenkotter, 1973) poses hazards to livestock development and public health. For these reasons, interest in the screening of medicinal plants for their anthelmintic activity has remained of great scientific interest despite extensive use of synthetic chemicals in clinical practices (Akhtar et al., 2000). Until today very little works are performed in our country to investigate the anthelmintic properties of indigenous medicinal plants in cattle. Considering all of these constraints, this work was undertaken with following objectives: i) screening of medicinal plants having in vitro anthelmintic activity, ii) prevalence of gastrointestinal nematodes in cattle of Sadar Upazila of Mymensingh district.

\section{Materials and Methods}

\section{Collection of fecal samples}

Fecal samples were collected from 1200 randomly selected cattle of Sadar upazila of Mymensingh district (100 month) were examined at various seasons (rainy seasons, summer and winter). Fecal samples were collected from the rectum of cattle by hand and kept in polythene bags and examined 
by Floatation method (Rahman et al., 1996). The simple test tube flotation method is a qualitative test for the detection of nematode and cestode eggs and coccidia oocysts in the faeces. It is based on the separating of eggs from faecal material and concentrating them by means of a flotation fluid with an appropriate specific gravity.

\section{Collection of indigenous medicinal plants}

Indigenous medicinal plants (Table-3) from different location of Bangladesh were collected and the plants material were dried in shade and then dried off in the hot air oven at $55-60^{\circ} \mathrm{C}$ to gain constant weight.

\section{Preparation of plants powder}

Powders were prepared by pulverizing the dried indigenous medicinal plants with the help of electric grinder. A 25-mesh diameter sieve was used to obtain fine dust and preserved them into airtight plastic container, till their use for extract preparation. Previously prepared plants powders were used for preparation of plants extract. Ten grams of each powder were taken in a $500 \mathrm{ml}$ beaker and separately mixed with $100 \mathrm{ml}$ of distilled water. Then the mixtures were stirred for 30 min by a magnetic stirrer $(6000 \mathrm{rpm})$ and left as such for next $24 \mathrm{hrs}$. The extracts were then filtered through a fine cloth and again through filter paper (Whatman No. 1). The filtered material was taken into round bottom flask and then concentrated by evaporation of water from filtrate in a water bath at $50^{\circ} \mathrm{C}$ till it reached the final volume of $10 \mathrm{ml}$. After the evaporation of water from filtrate, the condensed extracts were preserved in tightly corked-labelled bottle and stored in a refrigerator until used for screening of anthelmintic activity.

\section{Preparation of stock solution}

Stock solutions of plant extracts were prepared by diluting the condensed extracts with water. Different concentrations of each category of plant extracts were prepared by dissolving them in the water prior to anthelmintic screening.

\section{Collection and maintenance of adult gastrointestinal nematodes in the laboratory}

Collection of parasites from abomasum were done by following standard procedure as described by Taylor (1934) and Bell (1957). Viscera of cattle were collected from local market .The abomasums were opened through its lesser curvature with the help of scissors. The contents were emptied in glass jars containing normal saline. The abomasi were thoroughly washed and cleaned off ingesta and put in a different jar containing normal saline and left for an hour or two to release the attachments of parasites from the wall of the abomasum. The mucosal surface of the abomasum were rubbed carefully between the fingers to remove any remaining worms adhering to the abomasal wall. Finally the abomasal mucosa was examined with the help of a magnifying glass for any remaining parasites still adhering to the mucous lining of abomasum. The contents were washed several times with water and continued till the worms were free from debrises. The final wash was made with the normal saline. The sediments were examined in large petri-dishes over a black background. The parasites were collected with the help of curved needle and kept in normal saline. The parasites were cleared off debris by brushing with camel hairbrush or shaking in normal saline and identified according to the keys described by Rahman et al., (1996) and Yamaguti (1958). They were kept in petri-dishes containing normal saline incubated at $37^{\circ} \mathrm{C}$.

\section{In vitro screening of plant extracts for anthelmintic activity}

Screening of water extracts of plant at various concentration viz. $25 \mathrm{mg} / \mathrm{ml}, 50 \mathrm{mg} / \mathrm{ml}$ and $100 \mathrm{mg} / \mathrm{ml}$ were performed in the petri-dishes containing adult live stomach worms of cattle collected from slaughter house in Phosphate buffer saline (PBS). PBS (100ml) containing 50 adult worms (both male and female) were pipetted in 3 petri-dishes at ratio $0.1 \mathrm{ml}, 0.05 \mathrm{ml}$ and $0.025 \mathrm{ml}$ water extracts were then added, respectively. The drug-parasite petri-dishes were incubated for three hours at room temperature and the efficacy was observed by counting the dead parasites and expressed in percentages (\%). 


\section{Results and Discussion}

The prevalence of gastrointestinal nematodes was highest in the month of June and July. The prevalence of gastrointestinal nematodes in cattle are shown in the Table 1 and Table 2. Highest prevalence of gastrointestinal nematodes were found in rainy seasons (July-October) followed by summer (March-June) and winter seasons (November-February). Prevalence of strongyles (Haemonchus sp., Trichostrongylus sp., Oesophagostomum sp. and Mecistocirrus sp.) infection was highest followed by Bunostomum sp., Strongyloides sp., Trichuris sp. and Capillaria sp. Waruiru et al. (2001) observed the epidemiology of gastrointestinal nematodes of dairy cattle in Central Kenya. The total worm burden in the animals was highest during the rainy season (March-June and OctoberDecember) and lowest during the dry seasons (July-September and January-February). This result is in conformity with earlier reports made by Keyyu et al. (2006), Jager et al. (2005), Soca et al. (2003) and Yildirim et al. (2000).

Table 1. Prevalence of gastrointestinal nematodes in cattle in Kotoally thana of Mymensingh district during different seasons

\begin{tabular}{|l|c|c|c|c|}
\hline \multicolumn{1}{|c|}{ Name of Parasites } & \multicolumn{3}{c|}{ Prevalence percentage } \\
\cline { 2 - 5 } & Whole year & $\begin{array}{c}\text { Rainy } \\
\text { seasons }\end{array}$ & Summer & $\begin{array}{c}\text { Winter } \\
\text { seasons }\end{array}$ \\
\hline Gastrointestinal nematodes & $84.08 \%$ & $97 \%$ & $85.5 \%$ & $69.75 \%$ \\
\hline $\begin{array}{l}\text { Strongyles (Haemonchus sp., Trichostrongylus sp., } \\
\text { Oesophagostomum sp. and Mecistocirrus sp.) }\end{array}$ & $63.92 \%$ & $71 \%$ & $66.25 \%$ & $52 \%$ \\
\hline Bunostomum sp. & $26.33 \%$ & $29 \%$ & $27.25 \%$ & $22.75 \%$ \\
\hline Strongyloides sp. & $21.5 \%$ & $24.25 \%$ & $23.25 \%$ & $17 \%$ \\
\hline Trichuris sp. & $17.25 \%$ & $19.5 \%$ & $18 \%$ & $14.25 \%$ \\
\hline Capillaria sp. & $24.5 \%$ & $27 \%$ & $26 \%$ & $20 \%$ \\
\hline
\end{tabular}

Table 2. Prevalence of Gastrointestinal nematodes in cattle in Kotoally thana of Mymensingh district on monthly basis

\begin{tabular}{|l|c|c|c|c|c|c|}
\hline \multicolumn{1}{|c|}{ Month } & $\begin{array}{c}\text { Gastrointestinal } \\
\text { nematodes }\end{array}$ & Strongyles & Bunostomum & Strongyloides & Trichuris & Capillaria \\
\hline January & $62 \%$ & $46 \%$ & $20 \%$ & $14 \%$ & $12 \%$ & $18 \%$ \\
\hline February & $73 \%$ & $55 \%$ & $25 \%$ & $16 \%$ & $14 \%$ & $20 \%$ \\
\hline March & $74 \%$ & $57 \%$ & $22 \%$ & $18 \%$ & $13 \%$ & $22 \%$ \\
\hline April & $82 \%$ & $64 \%$ & $26 \%$ & $24 \%$ & $17 \%$ & $24 \%$ \\
\hline May & $86 \%$ & $68 \%$ & $29 \%$ & $26 \%$ & $20 \%$ & $28 \%$ \\
\hline June & $100 \%$ & $76 \%$ & $32 \%$ & $25 \%$ & $22 \%$ & $30 \%$ \\
\hline July & $100 \%$ & $72 \%$ & $33 \%$ & $28 \%$ & $20 \%$ & $28 \%$ \\
\hline August & $96 \%$ & $75 \%$ & $30 \%$ & $22 \%$ & $23 \%$ & $30 \%$ \\
\hline September & $97 \%$ & $70 \%$ & $28 \%$ & $25 \%$ & $18 \%$ & $26 \%$ \\
\hline October & $95 \%$ & $67 \%$ & $25 \%$ & $22 \%$ & $17 \%$ & $24 \%$ \\
\hline November & $76 \%$ & $58 \%$ & $24 \%$ & $21 \%$ & $15 \%$ & $23 \%$ \\
\hline December & $68 \%$ & $49 \%$ & $22 \%$ & $17 \%$ & $16 \%$ & $19 \%$ \\
\hline
\end{tabular}


The in vitro efficacy of different concentrations of water extracts of 20 plants against adult gastrointestinal nematodes are shown in the Table 3. Water extract of 20 indigenous plants showed potential in vitro activities against adult parasites. The efficacy of water extract of these plants at the concentrations of $25 \mathrm{mg} / \mathrm{ml}$ and $50 \mathrm{mg} / \mathrm{ml}$ was much lower than that of concentration of $100 \mathrm{mg} / \mathrm{ml}$ except tobacco plants. Tobacco plants $(25 \mathrm{mg} / \mathrm{ml}$ and $50 \mathrm{mg} / \mathrm{ml})$ showed $100 \%$ in vitro efficacy against gastrointestinal nematodes of cattle. Neem, barbados lilac, betel leaf, papaya, dodder, bitter gourd and white verticillia $(50 \mathrm{mg} / \mathrm{ml})$ showed $70-80 \%$ in vitro efficacy against gastrointestinal nematodes of cattle. Turmeric $(50 \mathrm{mg} / \mathrm{ml})$ was $88 \%$ effective in vitro against gastrointestinal nematodes of cattle. The plants $(100 \mathrm{mg} / \mathrm{ml})$ had highly significant activity $(90-100 \%)$ against adult gastrointestinal nematodes in vitro were : neem (leaves and bark), tobacco plant (leaves), barbados lilac (leaves and bark), betel leaf (leaves), pineapple (leaves), jute (leaves), turmeric (rhizome), garlic (bulbs), devil's tree (leaves), papaya (leaves), dodder (whole plant), bitter gourd (leaves and seeds), white verticillia (leaves) and chaste tree (leaves). Iqbal et al. (2006) observed in vitro anthelmintic activity of Nicotiana tabacum leaves against gastrointestinal nematodes of sheep. The in vitro inhibitory effect was evident from the paralysis and/or mortality of worms noted at 6-hours postexposure. Raje and Jangde (2003) found in vitro anthelmintic activity of decoction of Nicotiana tabacum against Haemonchus contortus of goats.

Table 3. In vitro anthelmintic efficacy of different concentrations of water extracts of 20 indigenous medicinal plants against adult gastrointestinal nematodes of cattle

\begin{tabular}{|c|c|c|c|c|c|c|c|}
\hline \multirow[t]{2}{*}{ SI. No. } & \multicolumn{4}{|c|}{ Indigenous plants } & \multicolumn{3}{|c|}{$\begin{array}{c}\text { Percent non-motile adult worms at } \\
\text { different concentrations of water extracts } \\
\text { of plant }\end{array}$} \\
\hline & Local name & Scientific name & English name & Part used & $25 \mathrm{mg} / \mathrm{ml}$ & $50 \mathrm{mg} / \mathrm{ml}$ & $100 \mathrm{mg} / \mathrm{ml}$ \\
\hline \multirow[t]{2}{*}{1.} & $\mathrm{Nim}$ & Azadirachta indica & Neem & Leaves & 22 & 74 & $100^{*}$ \\
\hline & $\mathrm{Nim}$ & Azadirachta indica & Neem & Bark & 32 & 76 & $100^{*}$ \\
\hline 2. & Tamak & Nicotiana tabacum & Tobacco plant & Leaves & $100^{*}$ & $100^{*}$ & $100^{*}$ \\
\hline \multirow[t]{2}{*}{3.} & Ghora Nim & Melia azedarach & Barbados lilac & Leaves & 26 & 78 & $100^{*}$ \\
\hline & Ghora Nim & Melia azedarach & Barbados lilac & Bark & 28 & 74 & $98^{*}$ \\
\hline 4. & Paan & Piper betle & Betel leaf & Leaves & 22 & 72 & $100^{*}$ \\
\hline \multirow[t]{2}{*}{5.} & Anaras & Ananas comosus & Pineapple & Leaves & 52 & 66 & $100^{*}$ \\
\hline & Anaras & Ananas comosus & Pineapple & Fruit & 18 & 40 & 64 \\
\hline 6. & Deshi pat & Corchorus capsularis & Jute & Leaves & 24 & 58 & $100^{*}$ \\
\hline 7. & Halud & Curcuma longa & Turmeric & Rhizome & 42 & 88 & $100^{*}$ \\
\hline 8 & Rashun & Allium sativum & Garlic & Bulbs & 50 & 80 & $100^{*}$ \\
\hline 9. & Chhatim & Istonia scholaris & Devil's tree & Leaves & 36 & 62 & $94^{*}$ \\
\hline \multirow[t]{2}{*}{10.} & Pepe & Carica papaya & Papaya & Leaves & 46 & 78 & $90^{*}$ \\
\hline & Pepe & Carica papaya & Papaya & Seeds & 14 & 28 & 68 \\
\hline 11. & Lebu & Citrus aurantifolia & Lime Tree & Leaves & 20 & 38 & 56 \\
\hline 12. & Swarnalata & Cuscuta reflexa & Dodder & Whole plant & 32 & 72 & $100^{*}$ \\
\hline 13. & Gamari & Gmelina arborea & White Teak & Leaves & 26 & 44 & 74 \\
\hline 14. & Kurchi & $\begin{array}{l}\text { Holarrhena } \\
\text { antidysenterica }\end{array}$ & Conessi tree & Leaves & 22 & 48 & 82 \\
\hline \multirow[t]{2}{*}{15.} & Karalla & Momordica charantia & Bitter Gourd & Leaves & 24 & 80 & $100^{*}$ \\
\hline & Karalla & Momordica charantia & Bitter Gourd & Seeds & 20 & 60 & $98^{*}$ \\
\hline 16. & Tulsi & pcimum basilicum & Sweet basil & Leaves & 16 & 56 & 84 \\
\hline 17. & Dondakalos & Leucas aspera & White verticillia & Leaves & 42 & 70 & $94^{*}$ \\
\hline 18. & Dalim & Punica granatum & Pomegranate & Leaves & 30 & 52 & 86 \\
\hline 19. & Bhui-Tulsi & Salvia plebeja & Sage & Leaves & 36 & 64 & 88 \\
\hline 20. & Nishinda & Vitex negundo & Chaste Tree & Leaves & 26 & 56 & $92^{*}$ \\
\hline
\end{tabular}

*Considered strong wormicidal 
It may be concluded that the medicinal plants and/or its extracts may be used against gastrointestinal nematodes of cattle in Bangladesh. The pharmacokinetics together with its toxic effects need further studies.

\section{Acknowledgements}

The financial support of BAURES, Bangladesh Agricultural University, Mymensingh for conducting the experiment is gratefully acknowledged.

\section{References}

Akhtar, M.S., Iqbal, Z., Khan, M.N. and Lateef, M. 2000. Anthelminitic activity of medicinal plants with particular reference to their use in animals in the Indo-Pakistan subcontinent. Small Rum. Res., 38: 99-107.

Bell, R.R. 1957. Survey of gastrointestinal parasites of cattle in North California. Am. J. Vet. Res., VII: 294.

Garrels, G. 1975. Gastro-intestinal parasitic infestation of cattle in some village of Dhaka and Tangail district in Bangladesh. Bang. Vet. J., 9(1-4): 9-10.

Iqbal, Z., Lateef, M., Jabbar, A., Ghayur, M.N. and Gilani, A.H. 2006. In vitro and in vivo anthelmintic activity of Nicotiana tabacum L. leaves against gastrointestinal nematodes of sheep. Phytother. Res., 20(1): 46-48.

Jager, M., Gauly, M., Bauer, C., Failing, K., Erhardt, G. and Zahner, H. 2005. Endoparasites in calves of beef cattle herds: management systems dependent and genetic influences. Vet. Parasitol., 131(3-4): 173-91.

Kaemmerer, K. and Butendotter, S. 1973. The problem of residues in meat of edible domestic animals after application or intake of organophosphate esters. Residure Review, 46:1.

Keyyu, J.D., Kassuku, A.A., Msalilwa, L.P., Monrad, J. and Kyvsgaard, N.C. 2006. Cross-sectional prevalence of helminth infections in cattle on traditional, small-scale and large-scale dairy farms in Iringa district, Tanzania. Vet. Res. Com., 30(1): 45-55.

Perry, B.D. and Randolph, T.F. 1999. Improving the assessment of the economic impact of parasitic diseases and of their control in production animals. Vet. Parasitol., 84: 145-168.

Perry, B.D., Randolph, T.F., McDermott, J.J., Sones, K.R. and Thornton, P.K. 2002. Investing in animal health research to alleviate poverty. International Livestock Research Institute, Nairobi, Kenya, 148 pp.

Qadir, A.N.M.A. 1981. An observation on the seasonal influence on the gastro-intestinal nematode infection in goats under farm conditions. Bang. Vet. J., 15(3-4): 11-15.

Rahman, M.H. Ahmed, S. and Mondal, M.M.H. 1996. Introduction to helminth parasites of animals and birds in Bangladesh. ${ }^{\text {st }}$ edn., Sheba Printing Press. Bangladesh.

Rahman, M.H. and Mondal, M.M.H. 1983. Helminth parasites of cattle (Bos tauras) in Bangladesh. Ind. J. Parasitol., 7: 173174.

Raje, A.A. and Jangde, C.R. 2003. In vitro anthelmintic activity of decoction of Nicotiana tabacum against Haemonchus contortus of goats. Ind. Vet. J., 80(4): 364-365.

Soca, M., Simon, L., Soca, M. and Garcia, E. 2003. Gastrointestinal nematodes of young cattle in commercial silvopastoral systems. I. "El Cangre" Livestock Enterprise. Pastos y Forrajes, 26(1): 47-52.

Taylor, E.L. 1934. A method of estimating the number of worms present in the 4th stomach and small intestine of sheep and cattle for the definite diagnosis of the parasitic gastritis. Vet. Res., 14: 474.

Waller, P.J. and Prichard, R.K. 1985. Drug resistance in nematodes. In: Campbell, W.C., Rew, R.S. (Eds), Chemotherapy of Parasitic Infections. Phenum, New York, USA, 339-362pp.

Waruiru, R.M., Thamsborg, S.M., Nansen, P., Kyvsgaard, N.C., Bogh, H.O., Munyua, W.K. and Gathuma, J.M. 2001. The epidemiology of gastrointestinal nematodes of dairy cattle in Central Kenya. Trop. Anim. Healt. Produc., 33(3): 173-187.

Yamaguti, S. 1958. Systema Helminthum. Interscience Publishers, Inc. New York, USA, 3: 410-451.

Yildirim, A., Kozan, E., Kara, M. and Oge, H. 2000. The prevalence of helminth infections in cattle raised in barns in Kayseri province. Ankara Universitesi Veteriner Fakultesi Dergisi, 47(3): 333-337. 